\title{
Evaluating The Welfare Cost Of Inflation In A Monetary Endogenous Growth General Equilibrium Model: The Case Of South Africa
}

Rangan Gupta, University of Pretoria, South Africa Josine Uwilingiye, University of Pretoria, South Africa

\begin{abstract}
This paper uses the general equilibrium monetary endogenous growth model of Dotsey and Ireland (1996), in which inflation distorts a variety of marginal decisions, to evaluate the welfare cost of inflation in South Africa - a country, where, since the February of 2000, the sole objective of the central bank has been to keep the inflation rate within the target band of 3 percent to 6 percent. Although individually none of the distortions is very large, they combine to yield substantial welfare cost estimates ranging between 0.70 percent of GDP to 1.33 percent of GDP for the lower and upper limits of the target band. More importantly, the welfare costs obtained here are at least three times more than those derived previously for the South African economy based on partial equilibrium approaches. These higher estimates, thus, tend to make a case for a possibly lower and narrower target band.
\end{abstract}

Keywords: Inflation; Growth; Welfare

\section{INTRODUCTION}

$\mathscr{J}$ he South African Reserve Bank (SARB) has been in pursuit of low inflation for nearly three decades now. Though not quite successful over the decade of 1980, the SARB made significant progress in reducing the inflation rate during the 1990s. Interestingly, the SARB pursued an implicit inflation target during the latter period. However, since the announcement made by the minister of Finance in February of 2000, the sole objective of the SARB has been to achieve and maintain price stability. In other words, the SARB has now adopted an explicit inflation targeting regime, whereby it aims to keep the CPIX ${ }^{1}$ inflation rate within the target band of 3 to 6 percent, using discretionary changes in the Repurchase (Repo) rate as its main policy instrument. In this regard, the measurement of the cost of inflation is of paramount importance in determining the legitimacy of the current target band and if there is a need to rethink of the level and width of the band in terms of the welfare cost of inflation at least. ${ }^{2}$

Given this, four recent studies by Gupta and Uwilingiye (2008, 2009a, b and c) deserve special mentioning. These four studies used alternative econometric methodologies to obtain estimates for the range of the welfare cost of inflation for the target band pursued by the SARB. While Gupta and Uwilingiye (2008) showed that the welfare cost of inflation ranged between 0.34 and 0.67 percent of Gross Domestic Product (GDP), obtained using the Johansen $(1991,1995)$ cointegration approach to estimate the long-run money demand function, Gupta and Uwilingiye (2009a) found the corresponding values to decrease markedly to 0.16 to 0.36 percent of GDP when the

\footnotetext{
${ }^{1}$ CPIX is defined as CPI excluding interest rates on mortgage bonds.

${ }^{2}$ For recent studies that have evaluated the South African inflation targeting regime in terms of average levels of inflation, volatility and a wide array of other macroeconomic variables, refer to Burger and Marinkov (2008), Gupta and Uwilingiye (forthcoming a, b) and Gupta et al. (forthcoming).
} 
long-horizon approach proposed by Fisher and Seater (1993) was used to estimate the long-run money demand function on the same data set. The difference between the results essentially emanated from the smaller sizes of the interest rate elasticity and semi-elasticity obtained under the long-horizon approach relative to the cointegration procedure. Realizing that the monetary aggregate and the interest rate variables are available at higher frequencies than the measure of income and that long-run properties of data are unaffected under alternative methods of time aggregation, Gupta and Uwilingiye (2009b), tested for the robustness of the two estimation procedures under temporal aggregation and systematic sampling. Their results indicated that the long-horizon method is more robust to alternative forms of time aggregation, and given this, the welfare cost of inflation in South Africa for the inflation target band of 3 to 6 percent was found to be between 0.15 and 0.41 percent of GDP.

However, Gupta and Uwilingiye (2009c) point out that welfare cost calculations obtained by integrating under the money demand curve as the interest rate rises from zero to a positive value to obtain the lost consumer surplus and then deducting the associated seigniorage revenue to deduce the deadweight loss, is merely onedimensional. This is because the consumer surplus approach fails to account for the fact that inflation, operating in conjunction with the tax system, has further distortionary effects on the intertemporal consumption choice (i.e., saving for old age), housing and the real cost of servicing government debt. Thus, the welfare costs obtained using the money demand approaches is likely to provide the lower limit of such estimates, and, hence, a more general approach is desired to obtain the "true" size of the welfare loss caused by inflation. As such, Gupta and Uwilingiye (2009c), using a microeconomic partial equilibrium approach as proposed by Feldstein (1997, 1999), found the annual deadweight loss of a two percent inflation rate to be 0.225 percent of GDP. Realizing that the calculations are symmetric and approximately linear, an inflation target band of 3 to 6 percent would imply the welfare cost to range between 0.34 percent and 0.68 percent of GDP. Interestingly, the figures are nearly the same as those obtained by Gupta and Uwilingiye (2008). Feldstein $(1997,1999)$ argued that costs of disinflation are temporary while the benefits are permanent; i.e., one needs to compare the discounted stream of benefits with one-off output costs. Given this, Gupta and Uwilingiye (2009c) calculated the present value gain to be 13.33 percent of GDP, while, the corresponding one-off output cost of moving from two percent inflation to price stability was found to be 0.034 percent of GDP. Thus, the gain was found to outweigh the cost by an overwhelming margin.

Dotsey and Ireland (1996) evaluated the welfare cost of inflation in dynamic general equilibrium endogenous and exogenous growth frameworks. By viewing inflation as a tax on micro-level decisions, the authors were able to identify explicitly, and quantify numerically, sizeable welfare costs of inflation at the macroeconomic level, indicating that Feldstein $(1997,1999)$-type partial equilibrium approaches, also used by Gupta and Uwilingiye $(2009 \mathrm{c})$, can significantly underestimate the cost of inflation. Given this, it is important that one revisit the welfare cost estimates for South Africa in a dynamic general equilibrium endogenous growth model to ensure that one correctly evaluates the inflation targeting regime, based on welfare cost estimates.

Against this backdrop, this paper calibrates the general equilibrium endogenous growth model proposed by Dotsey and Ireland (1996) for South Africa using quarterly data for the period 1965 to 2008 and obtains the welfare cost of inflation. The decision to use the framework proposed by Dotsey and Ireland (1996) over a large number of other general equilibrium models, such as Black et al. (1993), Coleman (1993), De Gregorio (1993), Gomme (1993), Jones and Manuelli (1993), Wang and Yip (1993), Marquis and Reffett (1994), and Whu and Zhang (1998), is due to the fact that the transactions technology used here generates a money demand function that has an interestelasticity similar to those estimated with South African data. Consequently, the model is ideally suited for comparing the welfare cost estimates obtained from the traditional partial equilibrium approaches based on money demand estimations to the full general equilibrium cost of inflationary policy. To the best of our knowledge, this is the first attempt to use a dynamic general equilibrium endogenous growth model to obtain the welfare cost of inflation in South Africa. 


\section{THE GENERAL EQUILIBRIUM MODEL}

In this study, we use Dotsey and Ireland's (1996) general equilibrium model. We start off by describing the economic environment, followed by the problems of the household, financial intermediary and the goods-producing firm. ${ }^{3}$

\section{Economic Environment}

The model economy consists of a continuum of markets, indexed by $i \in[0,1]$, arranged on the boundary of a circle with a circumference of one. In each market, a distinct, nonstorable consumption good is produced and traded in each period $t=0,1,2, \ldots$. Thus, the economy's consumption goods are also indexed by $i \in[0,1]$, implying that good $i$ is sold in market $i$.

Each market $i$ is populated with a large number of identical households, financial intermediaries, and goods-producing firms. We assume that enough symmetry exists amongst the agents' preferences, endowments and technologies to allow us to consider the behavior of a single representative agent corresponding to each type; i.e., households, intermediaries and firms. The representative agents all live at market 0 , so that the index $i$ measures the distance of market $i$ form their home.

At the beginning of period $t=0$, the government, which has no other role in the economy, supplies noninterest bearing fiat money of $m_{0}^{s}$ units to households and augments the initial supply with identical lump-sum transfers $h_{t}$ to all households at the beginning of each period $t$. Hence, per-household money supply $m_{t+1}^{s}$ at the end of period $t$ satisfies:

$m_{t+1}^{s}=\left(1+g_{t}\right) m_{t}^{s}$

where the rate of money growth $g_{t}$ is given by

$$
g_{t}=\frac{h_{t}}{m_{t}^{s}}
$$

Note: The government pre-announces the complete sequence $\left\{g_{t}\right\}_{t=0}^{\infty}$ of money growth rates at the beginning of period $t=0$, which leads all agents to have perfect foresight beyond this point.

\section{Household and Trading}

The representative household at market $i=0$ has preference over leisure $\left(J_{t}\right)$ and the entire continuum of consumption goods $\left(c_{t}(i)\right)$ as described by the utility function:

$$
\sum_{t=0}^{\infty} \beta^{t}\left\{\int_{0}^{1} \ln \left[c_{t}(i)\right] d i+B J_{t}\right\}, \quad \beta \in(0,1), B>0
$$

where $\beta$ is the discount rate and $B$ is the substitution elasticity between leisure and household consumption.

\footnotetext{
${ }^{3}$ The description of the general equilibrium model relies heavily on the discussion available in Dotsey and Ireland (1996) and has been presented here to ensure that the paper is self-contained. As such, we also retain the paper's symbolic representation of the equations.
} 
The representative household is assumed to be made up of two members - a shopper and a worker (Lucas and Stokey; 1983). The representative worker rents out his capital stock $k_{t}$ at the real rate $r_{t}$ and supplies $l_{t}^{g}$ units of labor at the real wage $w_{t}$ to goods-producing firms, at each time point $t$. He also supplies $l_{t}^{f}$ units of labor to financial intermediaries. In each period, the fraction of time allocated to each activity sums to one. The worker makes his labor-supply decisions subject to time constraint

$1 \leq J_{t}+l_{t}^{g}+l_{t}^{f}$

at each date $t$.

Meanwhile, the representative shopper travels around the circle to obtain goods for his household's consumption. As in Prescott (1987), Schreft (1992b) and Gillman (1993), the shopper chooses one of two ways to make payment for his purchases in each market $i$. First, he can make use of government-issued fiat money. Assuming perfect competition, the nominal price $p_{t}$ of consumption goods is the same across markets - the shopper may acquire $c_{t}(i)$ units of good $\mathrm{i}$ in exchange for $p_{t} c_{t}(i)$ units of money at time $t$. Second, he could use the services of a financial intermediary to purchase good $i$ on credit that will be paid at the end of the $t$ period from his labor and rental incomes. The credit is obtained at a cost of $\gamma(i)$ units of labor. An intermediary verifies the shopper's identity, proof of income and credit record and guarantees his ability to pay so that the firm in market $i$ is willing to sell its output on credit at time $t$. The transaction cost to be paid by the shopper to the intermediary does not depend on the quantity of purchases, but increases with distance; i.e., the farther the shopper travels from his residence, the greater the cost he has to incur. Hence, $\gamma$ is strictly increasing function of $i$. Under the additional assumption that $\lim _{i \rightarrow 1} \gamma(i)=\infty$, there will always be some cash-good, implying a well-defined money demand function.

The intermediary in market $i$ charges the representative household the real price $q_{t}(i)$ in exchange for its services at time $t$. Since the intermediary's cost $\gamma(i)$ is independent of the quantity of the transaction, but depends on $i$, competition implies that the representative shopper may acquire $c_{t}(i)$ units of good $i$ on credit at time $t$ at a total nominal cost of $p_{t}\left[c_{t}(i)+q_{t}(i)\right]$, where $p_{t} c_{t}(i)$ is the amount that the shopper has to pay for goods themselves (which is the same whether cash or credit is used to purchase the goods) and $p_{t} q_{t}(i)$ is the amount required to compensate the intermediary.

Let the indicator function $\xi_{\mathrm{t}}(\mathrm{i})=0$ if the representative shopper purchases good $i$ with money at time $t$, and let $\xi_{\mathrm{t}}(\mathrm{i})=1$ if he uses the services of an intermediary instead. To purchase goods with cash in period $t$, the shopper needs to have nominal money balance of $\mathrm{m}_{\mathrm{t}}$, which is augmented at the beginning of the period by the government transfer $h_{t}$. Since the shopper must use money whenever he chooses not to hire an intermediary, he faces the cash-in-advance constraint

$\frac{\mathrm{m}_{\mathrm{t}}+\mathrm{h}_{\mathrm{t}}}{\mathrm{p}_{\mathrm{t}}} \geq\left[1-\xi_{\mathrm{t}}(\mathrm{i})\right] \mathrm{c}_{\mathrm{t}}(\mathrm{i}) \mathrm{di}$

in each period $t$.

After making its consumption decision at the end of period $t$, the representative household participates in a centralized assets market and receives rental payments $r_{t} k_{t}$ and wages $w_{t}\left(l_{t}^{g}+l_{t}^{f}\right)$ and pays for the credit goods purchased earlier during period $t$. Whatever remains is then used to accumulate cash balances $m_{t+1}$ that he carries 
into period $t+1$ and to purchase the unsold output from the representative firm, which it combines with its depreciated capital stock $(1-\delta) k_{t}$ in order to carry $k_{t+1}$ units of capital into period $t+1$.

The household can also borrow from and lend to other households at the end-of-period asset market by purchasing or issuing one-period, nominally-denominated discounts bonds. In period $t+1$, bonds pay $b_{t+1}$ units of money and are sold for $b_{t+1} / R_{t}$ units of money in period $t$ asset market, where $R_{t}$ is the gross nominal interest rate between period $t$ and $t+1$. Note that $b_{t+1}=0$ must hold as an equilibrium condition in each period $t$ since these bonds are available in zero net supply at the beginning of each period.

As a source of income in period $t$, the representative household has access to its initial money and bond holdings, its beginning of period government transfer, its rental and wage receipts, and the undepreciated capital stock. On the expenditure side, the representative household purchases consumption goods, pays to the intermediaries, and also uses the available resources on capital, money, and bonds that it will carry into period $t+1$.

Formally, the representative household faces the budget constraint

$$
\frac{m_{t}+b_{t}+b_{t}}{P_{t}}+r_{t} k_{t}+w_{t}\left(l_{t}^{g}+l_{t}^{f}\right)+(1-\delta) k_{t} \geq \int_{0}^{1} c_{t}(i) d i+\int_{0}^{1} \xi_{t}(i) q_{t}(i) d i+k_{t+1}+\frac{m_{t+1}}{P_{t}}+\frac{b_{t+1}}{p_{t} R_{t}}
$$

in each period $t$. The representative household chooses sequences for $c_{t}(i), \xi_{t}(i), J_{t}, l_{t}^{g}, l_{t}^{f}, k_{t+1}, m_{t+1}$ and $b_{t+1}$ to maximize the utility function (3) subject to time constraint (4), cash-in-advance constraint (5) and the resource constraint (6) by taking the sequences of $h_{t}, r_{t}, w_{t}, p_{t}, q_{t}(i)$ and $R_{t}$ as given. Moreover, the household also takes its initial holdings of capital $k_{0}>0$, money $m_{0}=m_{0}^{s}$ and bonds $b_{0}=0$ as given.

\section{The Representative Intermediary's Problem}

In market $i$, an intermediary hires $\gamma(i)$ units of labor and charges $q_{t}(i)$ if the representative shopper purchases good $i$ on credit at time $t$. Thus, the representative intermediary chooses labor input $n_{t}^{f}$ to maximize its profits. Formally, at each date $t$,

$$
\pi_{t}^{f}=\int_{0}^{1} \xi_{t}^{s}(i) q_{t}(i) d i-w_{t} n_{t}^{f}
$$

is maximized taking $w_{t}, \xi_{t}^{s}$ and $q_{t}(i)$ as given, subject to the intermediary's total demand for labor (the technological constraint):

$$
n_{t}^{f} \geq \int_{0}^{1} \xi_{t}^{s}(i) \gamma(i) d i
$$

\section{The Representative Goods-producing Firm's Problem}

In market $i=0$, the representative goods-producing firm uses $k_{t}$ units of capital and $n_{t}^{g}$ units of labor in each period $t$ and produces consumption good $i=0$. Its profits in period $\mathrm{t}$ are: 


$$
\pi_{t}^{g}=A\left(k_{t}\right)^{\alpha}\left(n_{t}^{g}\right)^{1-\alpha}\left(K_{t}\right)^{\eta}-r_{t} k_{t}-w_{t} n_{t}^{g} \quad \alpha \in(0,1), \eta>0 .
$$

$K_{t}$ in production function equation (9) represents the aggregate capital stock per household at time $t$. Following Romer (1986), capital is broadly defined to include human capital and disembodied knowledge, over and above the physical capital. Spillover effects from human capital lead to increasing returns to scale at aggregate level, even though production obeys constant returns to scale at firm level. Increasing returns to scale results in endogenous growth, which is also (possibly) dependent on the inflation rate. When maximizing its profit, given in (9), the representative firm takes $K_{t}, r_{t}$ and $w_{t}$ as given.

\section{COMPETITIVE EQUILIBRIUM}

A competitive equilibrium in this economy consists of sequences for prices and quantities, which ensures that the optimization problems of households, intermediaries and firms, as outlined above, holds. Given the initial conditions $k=K_{0}>0, m_{0}=m_{0}^{s}$, and $b_{0}=0$, equilibrium prices and quantities must also satisfy the zero profit conditions of the goods-producing firms and the financial intermediaries; i.e.

$\pi_{t}^{g}=\pi_{t}^{f}=0$

the consistency condition

$k_{t+1}=K_{t+1}$

and the market-clearing conditions in each period $t$ for each market as follows :

Goods market: $A\left(k_{t}\right)^{\alpha+\eta}\left(n_{t}^{g}\right)^{1-\alpha}+(1-\delta) k_{t}=k_{t+1}+\int_{0}^{1} c_{t}(i) d i$

Labor market: $n_{t}^{g}=l_{t}^{g}$ and $n_{t}^{f}=l_{t}^{f}$,

Money market: $m_{t+1}=m_{t+1}^{s}$

Bond market: $b_{t+1}=0$

Financial intermediaries: $\xi_{t}(i)=\xi_{t}^{s}(i)$

\section{GENERAL EQUILIBRIUM EFFECTS OF INFLATION TAX}

Dotsey and Ireland (1996) demonstrate that there exists a borderline index $\mathrm{S}_{\mathrm{t}}$ for each date $t$, such that all the representative household's purchases are credit goods with indices $i \leq s_{t}$ and all goods are cash goods when $\mathrm{i}>\mathrm{s}_{\mathrm{t}}$, with the borderline index determined by the solution to

$\gamma\left(s_{t}\right)=\left[\ln \left(\lambda_{t}+\mu_{t}\right)-\ln \left(\lambda_{t}\right)\right] /\left(w_{t} \lambda_{t}\right)$ 
where $\lambda_{t}$ is non-negative multiplier on the resource constraint (6) and $\mu_{t}$ is the non-negative multiplier on the cashin-advance constraint (5) from the household's optimization problem. Note that since transaction cost increases with distance, the shopper uses credit close to home and cash far from home, as discussed in Schreft (1992) and Gillman (1993).

The representative household's optimal $c_{t}(i)$ follows a step-function in each period $t$

$$
c_{t}(i)=\left\{\begin{array}{ll}
c_{t}^{1}=1 / \lambda_{t} & \text { for } i \leq s_{t} \\
c_{t}^{0}=1 /\left(\lambda_{t}+\mu_{t}\right) & \text { for } i>s_{t}
\end{array}\right. \text {. }
$$

where, since $\mu_{t} \geq 0, \quad c_{t}^{1} \geq c_{t}^{0}$, equation (19) and cash-in-advance constraint (5) determine equilibrium money demand as:

$$
\frac{\left(m_{t}+b_{t}\right)}{p_{t}}=\left(1-s_{t}\right) c_{t}^{0}
$$

Further, equations (8), (14) and (17) determine the employment in the financial sector as:

$$
l_{t}^{f}=\int_{0}^{s_{t}} \gamma(i) d i
$$

In this model, welfare costs of inflation arise in a number of ways. First, higher inflation causes the cashin-advance constraint to bind, implying higher values of $\mu_{t}$ following higher rates of inflation. Since $\gamma$ is increasing function of $i$, the larger value of $\mu_{t}$ will lead to a higher value of $s_{t}$. Referring to equation (18), as $s_{t}$ increases, the representative household purchases a wider range of goods with the help of intermediaries. Second, based on equation (19), inflation tax distorts consumption and production decisions in two ways: 1) with $c_{t}^{1}>c_{t}^{0}$, the marginal rate of substitution between cash and credit goods differ from the corresponding marginal rate of transformation, with the representative household buying different consumption goods in different quantities and 2) since $c_{t}^{0}$ is a decreasing function of $\mu_{t}$, the representative household purchases cash goods in smaller quantities, causing a reduction in market activity. Given the production technology in equation (9), these allocative effects of inflation change the level and growth rate of aggregate output. Third, equation (20) suggests that as the inflation rate rises, the representative household economizes on its cash balances by not only purchasing a wider range of goods without money, but also by consuming less of cash goods. In other words, $s_{t}$ increases and $c_{t}^{0}$ decreases respectively, leading the money demand function to be interest-elastic and resulting in a Bailey-Friedman type cost of the inflation tax. Finally, equation (21) suggests that as $s_{t}$ increases following an increase in the inflation tax, the size of the labor force in the financial sector rises, causing a substitution of resources from the production sector and into finance. This also contributes to the welfare cost of inflation, since given the production function in equation (9), this allocative effect influences the long-run growth rate. Clearly then, inflation tax distorts many marginal decisions; however, it is not possible to analytically assess the magnitude of any of these distortions. Given this, one has to resort to numerical methods to measure the effects of the inflation tax in the general equilibrium which, in turn, requires us to calibrate the model - a process which we discuss in the next section. 


\section{MODEL CALIBRATION}

The household's discount rate is set at $\beta=0.99$ and the depreciation rate at $\delta=0.019$ (Liu and Gupta) so that the period in the model is one quarter year. To ensure growth in the long-run equilibrium, $\eta=(1-\alpha)=0.74$, given $\alpha=0.26$ (Liu and Gupta, 2007). With $A=0.3926$, the economy grows at a constant annual rate of 3 percent, the average growth rate of the South African economy for the period 1965-2008, under a constant annual inflation rate of 9.45 percent, again a figure which corresponds to the average for the above period. The households allocate $25 \%$ of their time to labor (Liu and Gupta, 2007) under an inflation rate of 9.48 percent when $B=3.5795$.

The magnitude of the Bailey-Friedman cost of inflation depends on the size of the tax base and the interest elasticity of money demand. When the intermediary's cost function is specialized to

$$
\gamma(i)=\gamma[i /(1-i)]^{\theta}, \gamma>0, \theta>0,
$$

one can choose the parameters $\gamma$ and $\theta$ so that the size of the tax base and the interest elasticity of money demand in the model correspond to figures in the South African economy.

As in Dotsey and Ireland (1996), the size of inflation tax base in the South African economy is measured by the fraction of all purchases that are made using money. Based on our calculations, using data for the period 1965-2008 from the South African Reserve Bank (SARB) suggests that South African households made 45 percent of their transactions using M1(A), implying a value of 0.45 for $1-S_{t}$ under 9.45 percent inflation in the model.

The money demand for M1 is estimated using annual data for the period 1965-2008 and yields

$\ln (v M 1)=2.29+2.75 R$,

where $v M 1$ is the income velocity of M1(A) and $R$ is the 91-day Treasury bill rate. The OLS coefficient on $R$ measures the long-run interest semi-elasticity of money demand. An analogous statistic in the model economy is

$$
\left[\ln \left(v_{9.45}\right)-\ln \left(v_{0}\right)\right] /\left(R_{9.45}-R_{0}\right)
$$

where $v_{9.45}$ and $v_{0}$ are the constant annual velocities of money and $R_{9.45}$ and $R_{0}$ are constant annual nominal interest rates that prevail under constant annual inflation rates of 9.45 percent and zero. By matching the tax base and the elasticity figures in the data and the model, we obtain $\gamma$ to be equal to 0.0078 and $\theta$ equal to1.83.

With this combination of $\gamma$ and $\theta$, the annual velocity of money under 9.45 percent of inflation produced by the model is 11.21 , which is very similar to the average velocity of 13.15 found in the South African data for the period 1965-2008. This justifies our identification of one model period as one quarter year.

\section{THE QUANTITATIVE EFFECTS OF INFLATION IN THE GENERAL EQUILIBRIUM MODEL}

In this section, we analyze the effects of a change in the money growth rate on the critical variables defining the general equilibrium model. Note that the effects of monetary policies, which require constant money growth rates, give rise to steady-state equilibria in which all variables grow at constant rates. In Table 1, we compare the steady-state equilibrium, under the average inflation rate of 9.45 percent, with those of the Friedman-rule, 0 percent, 2 percent, 3 percent and 6 percent of inflation. Recall, under the Friedman (1969) rule, one must ensure a zero nominal rate of interest which, in turn, implies that money supply is contracted at the rate of time preference, while the situation under zero percent corresponds to the case of price stability and the 3 and 6 percent of inflation capture the limits of the target band. 
The representative shopper uses cash to make a constant fraction of his purchases under a constant inflation rate. The model has been calibrated to ensure that the agent carries out 45 percent of his transactions using M1 under the steady-state inflation rate of 9.45 percent. As inflation gets higher, the shopper, understandably, uses money in a smaller range of transaction, implying a positive relationship between the velocity of money and the inflation rate. The model parameterization also ensures that the representative worker devotes 25 percent of his time to labor. As seen from Table 1, households substitute out-of-market activity as inflation rises and enjoy more leisure without the use of means of exchange, unlike market activity that requires either money or costly financial services. Further, besides the substitution effect, there is also a negative wealth effect as the inflation rate increases. As in Cooley and Hansen $(1989,1991)$, the substitution effect tends to dominate the wealth effect, causing the household's labor supply to fall as the inflation rate rises. The allocation of labor force, besides the total labor supply itself, gets affected with changes in the inflation rate. As shown in Table 1, though the fraction of labor force working in financial intermediaries is a small number (always less than 0.6 percent), it rises with the rate of inflation. The substitution of labor of the production sector into leisure and the financial intermediaries tends to negatively affect the growth rate of output through the spillover effects of aggregate activity. The effect of inflation on the growth rate, however, is quite small, in general, since 9.45 percent inflation causes the growth rate to fall from 3.11 to 3.01 percent.

Table 1: The welfare Cost of Inflation

\begin{tabular}{|l|c|c|c|c|c|c|}
\multicolumn{1}{c|}{} & \multicolumn{3}{c|}{ Annual inflation rate } \\
\cline { 2 - 7 } \multicolumn{1}{c|}{} & $\begin{array}{c}\text { Friedman } \\
\text { Rule }\end{array}$ & $\mathbf{0}$ & $\mathbf{2}$ & $\mathbf{3}$ & $\mathbf{6}$ & $\mathbf{9 . 4 5}$ \\
\hline Annual money growth & -0.0394 & 0.0300 & 0.0506 & 0.0609 & 0.0918 & 0.1273 \\
\hline Annual inflation & -0.0694 & -0.0011 & 0.0192 & 0.0293 & 0.0595 & 0.0943 \\
\hline Annual growth rate & 0.0323 & 0.0311 & 0.0309 & 0.0307 & 0.0304 & 0.0301 \\
\hline Fraction of time working & 0.2548 & 0.2527 & 0.2523 & 0.2522 & 0.2515 & 0.2514 \\
\hline Fraction of labour in finance & 0.0000 & 0.0022 & 0.0029 & 0.0033 & 0.0044 & 0.0056 \\
\hline Fraction of purchases with money, number & 1.0000 & 0.5639 & 0.5301 & 0.5160 & 0.4814 & 0.4511 \\
\hline Fraction of purchases with money, value & 1.0000 & 0.5596 & 0.5245 & 0.5098 & 0.4734 & 0.4412 \\
\hline Annual velocity & 4.9306 & 8.8199 & 9.4135 & 9.6869 & 10.4386 & 11.2091 \\
\hline Welfare cost (percentage of output) & -2.20 & 0.00 & 0.48 & 0.70 & 1.33 & 1.97 \\
\hline
\end{tabular}

Following Cooley and Hansen $(1989,1991)$ and Dotsey and Ireland (1996), the welfare cost of inflation is captured by the permanent percentage increase in the consumption of all goods that is required to make the representative household as well off under a positive rate of inflation as it is under price stability (under the zero rate of inflation). When we multiply this figure with the consumption output ratio, we are able to express it as percentage of output. Table 1 shows that the welfare cost is nearly 2 percent of output for a steady-state inflation rate of 9.45 percent. The corresponding values for inflation rates of 2,3 and 6 percent of inflation are $0.48,0.70$ and 1.33 percent of output. Finally, the welfare gain from adopting the Friedman-rule is equivalent to a 2.2 percent increase in output.

Importantly, the welfare cost values are much higher compared to those obtained for South Africa thus far by Gupta and Uwilingiye (2008, 2009a, b and c). Recall that Gupta and Uwilingiye (2009b), based on a money demand approach, conclude that for the inflation target band of 3 to 6 percent, the welfare cost ranged between 0.15 and 0.41 percent of GDP, while Gupta and Uwilingiye (2009c), using Feldstein's (1997, 1999) microeconomic partial equilibrium approach, found the annual deadweight loss of a two percent inflation rate to be 0.225 percent of GDP. Clearly, when one compares the welfare cost estimates of Table 1 with those obtained from Bailey-Friedmantype partial equilibrium analyses used by Gupta and Uwilingiye $(2008,2009 \mathrm{a}, \mathrm{b})$, one tends to obtain much smaller figures than those under the general equilibrium model since the former approach captures only a fraction of the total cost of inflation - the cost due to its effect on the velocity of money. In addition to this effect, inflation causes inefficient allocation of productive labor across its alternative uses. Even though the labor supply effects might seem small quantitatively, they end up contributing to the welfare cost of inflation enough to significantly outweigh the welfare cost estimates under the Bailey-Friedman-type money demand approach. In addition, by viewing inflation as a tax on a host of micro-level decisions, we obtain sizeable welfare costs of inflation at the macroeconomic level, 
thus indicating that Feldstein (1997, 1999)-type partial equilibrium approaches, as used by Gupta and Uwilingiye (2009c), can also significantly underestimate the cost of inflation.

\section{CONCLUSION}

Since February 2000, the sole objective of the SARB has been to keep the CPIX inflation rate within the target band of 3 to 6 percent, using discretionary changes in the Repo rate as its main policy instrument. In this regard, the measurement of the cost of inflation is of paramount importance in determining the legitimacy of the current target band and if there is a need to rethink of the level and width of the band in terms of the welfare cost of inflation, at least. Against this backdrop, this paper calibrates the general equilibrium endogenous growth model proposed by Dotsey and Ireland (1996) where the inflation tax distorts a variety of marginal decisions for South Africa using quarterly data for the period 1965 to 2008 and obtains the welfare cost of inflation.

A higher inflation rate causes the agents to inefficiently economize on their holdings of real cash balances, leads to substitution out-of-market activity by taking more leisure and diverting productive resources out of goods production and into financial intermediaries. The model shows that individually, none of these distortions is very large, but the various small distortions combine to yield substantial estimates of the total cost of inflation. More importantly, the estimates are much higher than the previous welfare cost values obtained by Gupta and Uwilingiye (2008, 2009a, b and c) based on the Bailey-Friedman-type money demand approach or the Feldstein (1997, 1999)type partial equilibrium approach. We show that for a target band of 3 to 6 percent, the welfare cost of inflation ranges between 0.70 percent of GDP and 1.33 percent of GDP. On the other hand, the Friedman-rule tends to produce welfare gains of the magnitude of 2.20 percent of GDP. These higher estimates, thus, tend to strengthen the case for a possibly lower and narrower target band - a proposal that Gupta and Uwilingiye (forthcoming a, b) have been calling for based on their findings that the inflation targeting has produced higher mean and variance of inflation than it would otherwise be if the SARB had continued to follow its earlier so-called eclectic approach to monetary policy. In general, our findings highlight the usefulness of general equilibrium models for the purposes of evaluating a policy regime. In our case, this amounts to indicating that unless all the distortions induced by a policy are considered; in other words, unless we undertake a general equilibrium approach, reliance on partial equilibrium approaches for measuring the welfare effect of inflation will grossly underestimate the "true" welfare cost.

\section{ACKNOWLEDGEMENT}

We would like to thank Professor Peter N. Ireland for many helpful comments. However, all remaining errors are ours.

\section{AUTHOR INFORMATION}

Rangan Gupta is a Professor, Department of Economics, University of Pretoria, Pretoria, 0002, South Africa, and is the corresponding author. Phone: +27 12420 3460, Email: Rangan.Gupta@up.ac.za.

Josine Uwilingiye is a Graduate Student, Department of Economics, University Of Pretoria, Pretoria, 0002, South Africa. Phone: +27 72425 1121, Email: josine.uwilingiye@up.ac.za.

\section{REFERENCES}

1. Bailey, M.J. (1956). "The welfare cost of inflationary finance”, Journal of Political Economy, 64: 93-110.

2. Burger, P. and Marinkov, M. 2008. Inflation targeting and inflation performance in South Africa. TIPS Working Paper.

3. Black, R. Macklem, T. and Poloz, S. (1993). Non-Superneutralities and some benefits of disinflation: A quantitative general equilibrium analysis, Manuscript (Research Department, Bank of Canada, Ottawa).

4. Coleman, W.J. II, (1993). Money, Interest, and capital in cash-in- advance economy, Manuscript (Department of Economics, Duke University, Durham, NC).

5. Cooley, T.F. and Hansen, G.D. (1989). "The inflation tax in a real business cycle model”, American Economic Review, 79: 733-748. 
6. Cooley, T.F. and Hansen, G.D. (1991). “The welfare cost of moderate inflations”, Journal of Money, Credit, and Banking, 23: 483-503.

7. $\quad$ De Gregorio, J. (1993). Inflation, taxation, and long-run growth. Journal of Monetary Economics 31, 271289.

8. Dotsey, M. and Ireland, P.N. (1996). “The welfare cost of inflation in general equilibrium”, Journal of Monetary Economics, 37:29-47.

9. Fisher, M. and Seater, J. (1993). "Long-Run Neutrality and Superneutrality in an ARIMA Framework" American Economic Review, 83: 402-415.

10. Feldstein, M. (1997). Capital Income Taxes and the Benefit of Price Stability. In M. Feldstein, ed., The Cost and Benefit of Price stability, Chicago, University of Chicago Press.

11. Feldstein, M. (1999). "The costs and benefits of going from low inflation to price stability", In Christina D. Romer and David H. Romer (eds), Reducing Inflation: Motivation and Strategy. Chicago: University of Chicago Press.

12. Friedman, M. (1969). "The Optimal Quantity of Money”. In the optimum quantity of money and Other essays. Chicago. Aldine Publishing Company.

13. Gillmax, M. (2009). "The Welfare Cost of Inflation in a Cash -in -Advance model with Costy Credits", Journal of Monetary Economics, 31:97-115.

14. Gomme, P. (1993). "Money and Growth revisited: Measuring the Costs of Inflation in an Endogenous Growth Model", Journal of Monetary Economics, 32: 51-77.

15. Gupta, R., Kabundi, A ., and Modise, M. P. (2009). "Has the SARB Become More Effective Post Inflation Targeting?" Forthcoming in Economic Change and Restructuring.

16. Gupta, R. and Uwilingiye, J. "Comparing South African Inflation Volatility across Monetary Policy Regimes: An Application of Saphe Cracking", Forthcoming in Journal of Developing Areas.

17. Gupta, R. and Uwilingiye, J. "Should the SARB Have Stayed Time Inconsistent?" Forthcoming in South African Journal of Economics.

18. Gupta, R and Uwilingiye, J. (2009a). "Measuring the Welfare cost of Inflation in South Africa: A reconsideration", South African Journal of Economic and Management Sciences, 12:137-146.

19. Gupta, R. and Uwilingiye, J. (2009b). "Time aggregation, Long-run money demand and welfare cost of inflation", Studies in Economics and Econometrics, 33: 95-109.

20. Gupta, R. and Uwilingiye, J. (2009c). "Some benefits of Reducing Inflation in South Africa", Working paper 200915, Department of Economics, University of Pretoria.

21. Gupta, R. and Uwilingiye, J. (2008). "Measuring the Welfare cost of Inflation in South Africa", South African Journal of Economics, 76:16-25.

22. Jones, L.E. and Manuelli, R.E. (1993). Growth and the effects of inflation, Manuscript (Kellogg School of Management, Northwestern University, Evanston, IL.)

23. Liu, D. G. and Gupta, R. (2007). "A Small-Scale DSGE Model for Forecasting the South African Economy", South African Journal of Economics, 75: 179-193.

24. Marquis, M.H. and Reffett, K. L. (1994). "New technology spillovers into the payment system", Economic Journal, 104: 1123-1138.

25. Lucas, R.E. jr. and Stockey, N. L. (1983). "Optimal Fiscal and Monetary Policy in an Economy Without capital”, Journal of Monetary economics, 12: 55-93.

26. Prescott, E.C. (1987). “A multiple means of payment model”, In W.A. Barnett and K.J, Singleton, eds., New approaches to monetary economics. Cambridge. Cambridge University Press.

27. Romer, P. M. (1986). "Increasing Returns and Long -run Growth", Journal of Political Economy. 94:1002-1037.

28. Schreft, S.L. (1992). "Welfare- Improving Credit Controls", Journal of Monetary Economics, 30:57-72.

29. Wang, P. and Yip, C.K. (1993). "Real effects of money and welfare costs of inflation in an endogenously growing economy with transactions costs”, Research Paper 9311. Research department, Federal Reserve Bank of Dallas.

30. Wu, Y. Zhang, J. (1998). "Endogenous growth and the welfare cost of inflation: a reconsideration", Journal of Economic Dynamics and Control, 22:265-482. 
NOTES 